\title{
NILAI MORAL ISLAM PADA PROSES PRODUKSI BAKSO DI DESA CIBEUNYING KECAMATAN MAJENANG
}

\author{
Tri Almunawaroh dan Laili Ulviah \\ STKIP Majenang \\ Email: tri_almun@yahoo.co.id, laili.ulviah09@gmail.com
}

\begin{abstract}
The use of hazardous ingredients in food is still often done. One of the foods most often found in the presence of dangerous chemical formalin as a preservative is meatballs. Meatballs themselves become one of the favorite food of Cibeunying villagers.. Cibeunying Village is a bustling village because it has many educational institutions that cause people from outside the area to visit and settle in the area. The use of dangerous preservatives shows the low value and morale of food producers. This study aims to describe and interpret the ethics of meatball producers' production in the village of Cibeunying. This type of research is descriptive with a quantitative approach. The data collection method uses tests and questionnaires. The collected data were analyzed using qualitative and quantitative analysis. The results showed that of the ten meatballs samples tested, four meatballs indicated formalin, but none contained borax and pork. Besides that, some meatballs producers are not honest, and they say they do not use formaldehyde in the positive test kit results in a formaldehyde test. Nevertheless, overall, more producers still pay attention to Islamic business ethics, so it can be said that the implementation of Islamic values and morals in producing meatballs sold in Cibeunying village, Majenang sub-district, in general, is good.
\end{abstract}

Keywords: Islamic Moral Values, Producers, and Meatballs.

\begin{abstract}
Abstrak
Penggunaan bahan berbahaya pada makanan masih sering dilakukan. Salah satu makanan yang paling sering dijumpai adanya zat kimia berbahaya formalin sebagai pengawet adalah bakso. Bakso sendiri menjadi salah satu makanan favorit penduduk desa Cibeunying. Desa Cibeunying merupakan desa yang ramai karena memiliki banyak lembaga pendidikan yang menyebabkan orang-orang dari luar daerah berkunjung dan menetap di daerah tersebut. Penggunaan bahan pengawet berbahaya menunjukan rendahnya nilai dan moral produsen makanan. Penelitian ini bertujuan untuk menggambarkan dan menginterpretasikan etika produksi para produsen bakso di desa Cibeunying. Jenis penelitian ini adalah deskriptif dengan pendekatan kuantitatif. Metode pengumpulan datanya menggunakan tes dan kuesioner. Data yang telah terkumpul dianalisis menggunakan analisis kualitatif dan kuantitatif. Hasil penelitian menunjukan bahwa dari 10 sampel bakso yang diuji terdapat 4 bakso yang terindikasi formalin, tetapi tidak ada yang mengandung boraks dan daging babi. Disamping itu terdapat produsen bakso yang kurang jujur, mereka mengatakn tidak menggunakan formalin pada hasil tes kit yang positif pada uji formalin. Walaupun demikian, tetapi secara keseluruhan lebih banyak produsen yang masih memperhatikan etika bisnis Islam, sehingga dapat dikatakan Implementasi nilai dan moral Islam dalam memproduksi bakso yang dijual di desa Cibeunying kecamatan Majenang secara umum adalah baik.
\end{abstract}

Kata Kunci: Nilai Moral Islam, Produsen, dan Bakso. 


\section{PENDAHULUAN}

Orang Indonesia tergolong masyarakat yang beragama dan religius, tetapi hal tersebut tidak dapat menjamin makanan yang diproduksinya baik dan halal. Hal tersebut dibuktikan dengan adanya hasil penelitian yang menunjukan masih terdapat makanan yang mengandung zat kimia berbahaya ataupun mengandung unsur yang haram. Seperti penelitian yang dilakukan oleh Adi Saputrayadi terhadap bakso yang dijual di kota Mataram, dari 12 sampel yang dikumpulkan menunjukkan bahwa tidak ada yang mengandung boraks (0\%), tetapi 100 $\%$ mengandung formalin (Saputrayadi, Asmawati, \& Marianah, 2018)

Temuan bahan pengawet bukan hanya dalam bentuk formalin, tetapi juga dalam bentuk boraks, dalam Dedy Suseno disebutkan bahwa penelitian terhadap bakso dikota Medan menunjukkan bahwa 8 dari 10 sampel bakso yang diperiksa ternyata mengandung boraks dengan konsentrasi $0,08 \%$ - 0,29\% (Suseno, 2019). Hasil analisis boraks menggunakan spektrofotometer Uv-Vis menunjukkan bahwa 9 dari 12 positif mengandung boraks dengan konsentrasi terbesar pada sampel B1 sebesar 2414.375 $\mu \mathrm{g} / \mathrm{mL}$ (Suseno, 2019).

Selain itu, di Surabaya terdapat softgellcandy yang tak berlabel halal dijual secara bebas. Penelitian yang dilakukan oleh Yuanita Rachmawati menunjukan bahwa dari 15 sampel penelitian, 8 sampel terindikasi kandungan DNA babi ditandai dengan pita DNA sebesar \pm 149 bp (Rachmawati, Rokhim, Munir, \& Agustina, 2018). Fakta ini cukup memprihatinkan mengingat masyarakat Indonesia yang mayoritas beragama muslim dan tentu sangat memperhatikan kehalalan makanan yang di makannya, karena Allah memerintahkan manusia memakan-makanan yang halalan thoyyiban, maksudnya adalah selain aman, makanan yang dikonsumsi juga harus halal. Seperti yang telah dijelaskan dalam surat al-Baqarah, berikut:

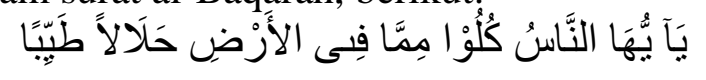

"Hai sekalian manusia, makanlah yang halal lagi baik dari apa yang terdapat di bumi..." (QS. Al-Baqarah (2): 168).

Bakso merupakan jajanan yang sangat diminati oleh seluruh lapisan masyarakat. Rasanya yang gurih dipadu dengan kuah hangat yang menyegarkan membuat masyarakat tidak pernah bosan walau makan sesering mungkin. Tetapi akan sangat fatal jika makanan yang sering dikonsumsi mengandung racun bagi tubuh.

Desa Cibeunying kecamatan Majenang merupakan desa yang padat penduduk dan tersebar beberapa pedagang bakso disetiap jalan utamanya. Menurut pengamatan penulis, warga desanya tergolong religius, karena terdapat pondok pesantren yang cukup besar dan sangat dekat dengan warga masyarakatnya. Selain itu di desa Cibeunying kecamatan Majenang terdapat 2 perguruan tinggi, beberapa sekolah, dan madrasah, sehingga tidak mengherankan jika banyak mahasiswa dan pelajar yang kost ataupun mondok di pesantren. Selain warga desa Cibeunying kecamatan Majenang, para mahasiswa dan pelajar juga sangat gemar mengkonsumsi bakso. Itu artinya bakso di desa Cibeunying dikonsumsi oleh banyak orang. Tidak semua pedagang bakso berasal dari desa Cibeunying, terdapat beberapa pedagang yang berasal dari luar daerah.

Untuk membangun kultur bisnis yang sehat, idealnya dibentuk atas rumusan etika yang akan digunakan sebagai norma perilaku sebelum aturan hukum perilaku dibuat dan dilaksanakan. Etika berperan sebagai kontrol terhadap individu pelaku bisnis melalui penerapan kebiasaan atau budaya moral atas pemahaman nilai moral yang menjadi kekuatan suatu perusahaan dengan mengutamakan kejujuran, disiplin, bertanggung jawab dan berperilaku tanpa diskriminasi (Aziz, 2013). Etika dalam berbisnis merupakan sesuatu hal yang tidak dapat diabaikan (Bakhri, Leliya, \& Purnama, 2018), sebab bisnis berkaitan secara langsung terhadap masyarakat luas 
dan etika bisnis berfungsi menjamin bergulirnya kegiatan bisnis pada jangka panjang.

Dari uraian di atas, penulis merasa tertarik dengan penelitian yang mampu mengkaji bagaimana implementasi nilai dan moral Islam dalam memproduksi bakso yang dijual di desa Cibeunying kecamatan Majenang?

\section{LITERATURE REVIEW}

Berkenaan dengan nilai nilai moral dalam kaitanya dengan produksi makanan, sudah ada beberapa penelitian yang melakukan penelitian terkait dengan etika bisnis Islam dan etika bagaimana menjalankan sebuah usaha.

Pertama, Noorma yunia melakukan penelitian dengan judul "Implementasi Etika Bisnis Islam Dalam Menjalankan Usaha Kecil", Hasilnya menunjukkan bahwa Kampoeng Kreati, Bazar Madinah dan Usaha Kecil di Lingkungan UIN Jakarta telah menerapkan etika bisnis Islam, baik oleh pengusaha maupun karyawannya, Dalam menjalankan usaha dan kegiatan, para pelaku usaha telah memahami dan mengimplementasikan prinsip atau nilainilai Islam dengan berlandaskan pada $\mathrm{Al}$ Qur'an dan Hadits (Yunia, 2018). Kelebihan dari penelitian ini adalah Noorma meneliti etika dari semua aspek, baik itu aspek prinsip, manajemen, marketing/iklan dan produk/harga, sayangnya dia hanya menggunakan studi literatur serta meresume hasil riset sebelumnya, sehingga tidak dapat dipastikan bahwa situasi saat dia meneliti dan saat riset sebelumnya dilakukan keadaannya masih sama.

Penelitian kedua dilakukan oleh Tika Safitri melakukan penelitian dengan judul "Penerapan Etika Bisnis Islam Dalam Kegiatan Produksi Kue Geti UD. Primadona Di Desa Jabalsari". Hasil penelitiannya menunjukkan bahwa UD. Primadona yang memproduksi kue geti telah melakukan kegiatan produksi sesuai dengan prinsip etika bisnis, yang terdiri dari prinsip kesatuan, yaitu dengan memilih penggunaan bahan baku yang halal dan berkualitas baik; prinsip keadilan, yaitu kesesuaian antara berat dan ukuran dengan keterangan yang tercantum pada kemasan; prinsip kehendak bebas, yaitu menjalankan perjanjian dengan konsumen sesuai dengan kesepakatan jani yang telah dibuat; prinsip tanggung jawab, yakni selalu terbukan dan siap bertanggungjawab atas adanya kecacatan produk; prinsip kebenaran, bahan baku yang digunakan telah sesuai dengan informasi yang tertera pada kemasan (Safitri, 2018). Selain itu, penelitiannya juga mengungkapkan bahwa UD. Primdona telah menerapkan prinsip ekonomi islam lainnya seperti prinsip keadilan, ketepatan takaran, kebenaran kesesuaian dalam produksi islami serta menghindari jenis dan proses produksi yang diharamkan dalam islam.

Penelitian lainnya terkait nilai moral pada proses produksi, dapat kita ketahui pada penelitian Risa Oktriana yang berjudul "Usaha Bakso Dalam Meningkatkan Pendapatan Keluarga Menurut Perspektif Islam”. Berdasarkan hasil penelitiannya, mekanisme kerja usaha bakso bakar secara keseluruhan telah sesuai dengan prinsip ekonomi islam. Hal ini dapat dilihat pada bahan dasar yang digunkaan untuk membuat bakso bakar adalah menggunakan bahanbahan yang aman, sesuai standar dan terjaga kebersihannya (Oktriana, 2014). Temuan lain yang dapat kita ketahui berdasarkan hasil penelitian ini adalah terkait aspek modal dan proses pemasaran bakso bakar yang juga telah sesuai dengan prinsip Ekonomi Islam. Selain itu, usaha bakso bakar yang dilakukan di Kota Bangkinan ini juga dinilai telah berkontribusi positif terhadap peningkatan pendapatan keluarga karena dapat menghadirkan lapangan kerja baru sekaligus bentuk peningkatan kesejahteraan ekonomi keluarga.

Penelitian Fitri Amalia tentang "Etika Bisnis Islam: Konsep dan Implementasi Pada Pelaku Usaha Kecil”. Dalam penelitiannya menyebutkan bahwa etika bisnis islam telah diterapkan oleh para pelaku usaha Kampung Kreatif, Bazaar 
Madinah dan para pelaku usaha di lingkungan Kampus UIN Syarif Hidayatullah yang mana dalam pelaksanaanya mereka meyakini bahwa kegiatan usaha bukan semata-mata dilakukan hanya untuk mendapatkan profit, namun juga untuk mendapatkan berkah dan ridha dari Allah SWT (Amalia, 2013). Hasil penelitiannya juga mengungkapkan bahwa segala kegiatan bisnis harus dilakukan dengan cara-cara terbaik seperti menghindari kecurangan, riba, penipuan serta tindakan zhalim lainnya. Pentingnya meningkatkan kesadaran etika dalam berbisnis sebagai bentuk kesadaran diri sendiri terhadap hal baik dan buruk, juga tentang hal yang haram dan halal.

Diantara beberapa penelitian terdahulu yang telah penulis paparkan diatas, ternyata belum ada yang melakukan penelitian secara khusus dan komprehensif tentang etika produksi pada bakso, dimana akan sangat besar dampaknya jika suatu kegiatan usaha makanan tidak dilakukan produksi sesuai aturan moral Islam. Selain objek dan subjek penelitian yang berbeda, metode dan pendekatannya pun berbeda dengan keempat topik penelitian sebelumnya.

\section{METODE PENELITIAN}

Jenis penelitian ini adalah deskriptif dengan pendekatan kuantitatif. Penelitian deskriptif menurut (Amalia, 2013) adalah penelitian yaang bertujuan untuk mengetahui nilai variabel mandiri baik itu variabel dependen maupun independen tanpa membuat perbandingan dan menghubungkan dengan antar variabel tersebut. Oleh sebab itu, penelitian ini penulis lakukan adalah untuk menggambarkan dan menginterpretasikan etika produksi para produsen bakso. Populasinya adalah penjual bakso di desa Cibeunying yang memproduksi baksonya sendiri.

Teknik pengumpulan data yang digunakan dalam penelitian ini adalah:

1. Observasi, digunakan untuk mengetahui banyaknya produsen bakso, mengetahui keadaan tempat produksi, kebersihan lingkungan tempat produksi, dan lain-lain

2. Tes. Tes dilakukan secara sederhana menggunakan tes kit formalin, tes kit boraks, dan pork detection kit, tes ini digunakan untuk mengetahui ada/tidak ada kandungan formalin, boraks dan kandungan daging babi pada bakso yang diproduksi di desa Cibeunying.

3. Kuesioner. Digunakan untuk mengetahui tujuan, motivasi dan apa yang diproduksi oleh produsen bakso di desa Cibeunying.

Analisis data yang digunakan dalam penelitian ini adalah analisis kuantitatif dan analisis kualitatif. Mula-mula akan dilakukan uji test sederhana menggunakan tes kit, untuk mengetahui apakah bakso tersebut mengandung boraks, formalin dan unsur babi. hasil uji ini berbentuk data kualitatif. Sedangkan hasil kuesioner akan dianalisis menggunakan analisis kuantitatif untuk mengetahui nilai dan moral Islam dalam produksi bakso di desa Cibeunying.

Kuesioner disusun dalam bentuk kuesioner dan disediakan empat opsi pilihan dengan teknik skala penilaian. Keseluruhan kuesioner di susun dengan teknik self report, yaitu dengan meminta responden untuk memberikan penilaian sesuai dengan tanggapan atau keadaan mereka. Alternatif pilihan yang disediakan terdiri atas Selalu, Sering, Jarang dan Tidak Pernah. Untuk pernyataan positif, masing-masing pilihan ini diberikan bobot penilaian 4 untuk pilihan "Selalu" (SL), 3 untuk pilihan "Sering" (S), 2 untuk pilihan "Jarang" (J), 1 untuk pilihan "Tidak Pernah" (TP). Untuk pernyataan negative skor nilai diterapkan secara terbalik. Untuk memastikan validitas dan reliabilitasnya, maka dilakukan pengujian. Uji validitas dan uji realibilitas dilakukan dengan menggunakan bantuan program SPSS. Data kuesioner yang diperoleh diuji validitasnya dengan tujuan untuk untuk melihat kevalidan dari masing-masing butir pernyataan. Tiap butir pernyataan dikatakan valid apabila nilai $r$ hitung lebih besar dari $r$ 
tabel dengan signifikansi 0,05. $\mathrm{r}$ tabel dalam uji validasi ini adalah sebesar 0,444. Jadi, butir pernyataan dikatakan valid apabila hasil $r$ hitung atau hasil validasinya lebih besar dari 0,444. Dan untuk uji reliabilitas, Semakin tinggi nilainya, semakin meyakinkan bahwa pengukuran memberikan hasil yang konsisten. Dengan mengetahui tingginya koefisien reliabilitas kuesioner dapat menentukan bahwa skor hasil ukur tes dapat dipercaya.

Teknik analisis yang digunakan dalam penelitian ini adalah rata-rata hitung. Perhitungan rata-rata untuk data yang tersusun menggunakan rumus:

$$
X=\frac{\Sigma f i X i}{\Sigma f i}
$$

Dari rata-rata hitung selanjutnya dicari nilai presentasenya dan selanjutnya berdasarkan presentase tersebut di definisikan berdasarkan kriteria pada Tabel 1 .

Tabel 1. Kriteria Penilaian

\begin{tabular}{cc}
\hline Besar Presentase $(\%)$ & Kriteria \\
\hline $0-20$ & Tidak Baik \\
$21-40$ & Kurang Baik \\
$41-60$ & Cukup Baik \\
$61-80$ & Baik \\
$81-100$ & Baik Sekali \\
\hline
\end{tabular}

\section{PEMBAHASAN DAN DISKUS \\ Hasil Penelitian}

Dari 10 sampel yang telah diuji, ada 4 yang terbukti terindikasi menggunakan bahan berbahaya dalam bentuk formalin, yaitu bakso B, C, D, dan E. Tabung E adalah tabung dengan perubahan warna ungu paling pekat, dilanjutkan $\mathrm{B}$ diurutan nomer 2 pekat warna ungu setelah E. Sedangkan C sedikit ada perubahan warna ungu namun tidak terlalu kentara.

Hasil uji boraks dari uji kualitatif menggunakan alat tes kit menyatakan bahwa dari 10 sampel tidak ada yang terindikasi bahan berbahaya boraks. Adapun hasil pengujian dari pork deection kit terhadap 10 sampel yang telah dikumpulkan dari para produsen bakso di desa Cibeunying terbukti tidak ada yang mengandung daging babi, karena hasil tes menunjukan hanya muncul 1 garis berwarna pada test strip.

Selanjutnya akan ditunjukan hasil pengisian kuesioner terhadap 10 responden, dimana hasil ini menunjukan kriteria penilaian etika dan moral Islam dari produsen bakso di desa Cibeunying.

Tabel 2. Hasil Perhitungan Kuesioner Tiap Responden

\begin{tabular}{|c|c|c|c|c|c|}
\hline $\begin{array}{l}\mathbf{N} \\
\text { o. }\end{array}$ & $\begin{array}{c}\text { Sampe } \\
l\end{array}$ & $\begin{array}{c}\text { Rat } \\
\text { a- } \\
\text { rat } \\
\text { a }\end{array}$ & $\begin{array}{c}\text { Persen } \\
\text { tase }\end{array}$ & $\begin{array}{c}\text { Krite } \\
\text { ria }\end{array}$ & $\begin{array}{l}\text { Kate } \\
\text { gori }\end{array}$ \\
\hline 1 & $\begin{array}{l}\text { Respo } \\
\text { nden } 1\end{array}$ & $\begin{array}{c}3,3 \\
5\end{array}$ & 83,75 & $\begin{array}{c}\text { Baik } \\
\text { sekali }\end{array}$ & A \\
\hline 2 & $\begin{array}{l}\text { Respo } \\
\text { nden } 2\end{array}$ & $\begin{array}{c}3,4 \\
5\end{array}$ & 86,25 & $\begin{array}{c}\text { Baik } \\
\text { sekali }\end{array}$ & A \\
\hline 3 & $\begin{array}{l}\text { Respo } \\
\text { nden } 3\end{array}$ & $\begin{array}{c}3,6 \\
5\end{array}$ & 91,25 & $\begin{array}{c}\text { Baik } \\
\text { sekali }\end{array}$ & A \\
\hline 4 & $\begin{array}{l}\text { Respo } \\
\text { nden } 4\end{array}$ & 3,3 & 82,5 & $\begin{array}{l}\text { Baik } \\
\text { sekali }\end{array}$ & A \\
\hline 5 & $\begin{array}{l}\text { Respo } \\
\text { nden } 5\end{array}$ & 3,7 & 92,5 & $\begin{array}{l}\text { Baik } \\
\text { sekali }\end{array}$ & A \\
\hline 6 & $\begin{array}{l}\text { Respo } \\
\text { nden } 6\end{array}$ & 3,1 & 77,5 & Baik & B \\
\hline 7 & $\begin{array}{l}\text { Respo } \\
\text { nden } 7\end{array}$ & 3,5 & 87,5 & $\begin{array}{l}\text { Baik } \\
\text { sekali }\end{array}$ & A \\
\hline 8 & $\begin{array}{l}\text { Respo } \\
\text { nden } 8\end{array}$ & $\begin{array}{c}3,6 \\
5\end{array}$ & 91,25 & $\begin{array}{l}\text { Baik } \\
\text { sekali }\end{array}$ & A \\
\hline 9 & $\begin{array}{l}\text { Respo } \\
\text { nden } 9\end{array}$ & $\begin{array}{c}2,1 \\
5\end{array}$ & 53,75 & $\begin{array}{c}\text { Cuku } \\
\mathrm{p} \\
\text { baik }\end{array}$ & $\mathrm{C}$ \\
\hline $\begin{array}{l}1 \\
0\end{array}$ & $\begin{array}{l}\text { Respo } \\
\text { nden } \\
10\end{array}$ & $\begin{array}{c}2,8 \\
5\end{array}$ & 71,25 & Baik & B \\
\hline \multicolumn{3}{|c|}{ Rata-rata } & $\begin{array}{c}817,5 \\
= \\
81,75\end{array}$ & $\begin{array}{c}\text { Baik } \\
\text { sekali }\end{array}$ & $\mathrm{A}$ \\
\hline
\end{tabular}

Berdasarkan tabel tersebut, etika dan moral produsen bakso di desa Cibeunying berada dalam kategori sangat baik. 
Hasil dan Pembahasan

1. Uji kandungan formalin pada bakso

\begin{tabular}{|c|c|c|c|c|}
\hline No & Indikator & Rata-rata & Presentase & Kriteria \\
\hline 1 & $\begin{array}{l}\text { Pengolahan } \\
\text { SDA (hewan) }\end{array}$ & 2,25 & 56,25 & $\begin{array}{c}\text { Cukup } \\
\text { baik }\end{array}$ \\
\hline 2 & $\begin{array}{l}\text { Motivasi } \\
\text { produksi, }\end{array}$ & 3,7 & 92,5 & $\begin{array}{l}\text { Baik } \\
\text { sekali }\end{array}$ \\
\hline 3 & $\begin{array}{l}\text { Memproduksi } \\
\text { makanan halal }\end{array}$ & 4 & 100 & $\begin{array}{c}\text { Baik } \\
\text { sekali }\end{array}$ \\
\hline 4 & $\begin{array}{l}\text { Target } \\
\text { swasembada } \\
\text { individu dan } \\
\text { masyarakat. }\end{array}$ & 3,53 & 88,12 & $\begin{array}{c}\text { Baik } \\
\text { sekali }\end{array}$ \\
\hline \multicolumn{3}{|c|}{ Rata-rata } & 84,23 & $\begin{array}{c}\text { Baik } \\
\text { sekali }\end{array}$ \\
\hline
\end{tabular}

Dalam Kamus Besar Bahasa Indonesia disebutkan bahwa formalin adalah larutan bening berbau menyengat, mengandung sedikit metanol untuk bahan pengawet dan pembunuh kuman. Penggunaan formalin pada makanan dapat berdampak buruk bagi kesehatan, seperti yang dijelaskan dalam jurnal Kesmas disebutkan bahwa formalin dapat bereaksi cepat dengan lapisan lendir saluran pencernaan dan saluran pernafasan. Di dalam tubuh cepat teroksidasi membentuk asam format terutama di hati dan sel darah merah. Pemakaian formalin pada makanan dapat mengakibatkan keracunan yaitu rasa sakit perut yang akut disertai muntah-muntah, timbulnya depresi susunan syaraf atau kegagalan peredaran darah(Wardani, Mulasari, Kesehatan, Universitas, \& Dahlan, 2016). Karena begitu besar efek negative formalin bagi kesehatan karena itu pemerintah melarang penggunaannya pada makanan. Dari kuesioner yang diberikan kepada responden, semua orang menjawab tidak pernah menggunakan zat kimia berbahaya formalin untuk bakso yang diproduksinya. Tetapi pada uji laboratorium sederhana yang dilakukan menggunakan tes kit formalin menunjukan ada beberapa sampel yang terindikasi zat kimia berbahaya formalin. Itu artinya terdapat produsen yang tidak jujur dan tak mengindahkan etika dalam produksi.
Walaupun kadar kandungan formalin pada setiap sampel bakso berbeda-beda, tetapi tetap saja dilihat dari etikanya produsen memiliki tabiat buruk dalam melaksanakan kegiatan ekonomi. Entah karena tidak ingin rugi ataupun alasan lain, entah banyak atau sedikit dalam mencampurkan formalin pada bakso, tetap saja itu tidak bisa dibenarkan dan tidak bisa ditolerir. Karena tujuan mereka memproduksi tidak sesuai dengan tujuan produksi dalam Islam, sebagaimana yang dikatakan oleh Yususf Qardhawi, bahwa tujuan produksi adalah (Qaradhawi, 1997):
a. Untuk memenuhi kebutuhan
b. Untuk kemaslahatan keluarga
c. Untuk kemaslahatan masyarakat
d. Untuk membangun/bekerja dan memakmurkan bumi

Dari hasil penelitian dapat dikatakan bahwa masih sebagian produsen bakso di desa Cibeunying yang melaksanakan produksi dengan tujuan yang diharapkan sesuai etika bisnis Islam. Mereka bekerja untuk memenuhi kebutuhan keluarga, bekerja demi kemaslahatan keluarga, dan untuk memakmurkan bumi, mengolah sumber daya yang ada untuk dimanfaatkan sebesar-besar kemakmuran manusia. Membuka lapangan pekerjaan, membantu meringankan beban sesama. Tetapi ada satu niat dan tujuan mulia yang oleh sebagian produsen dilupakan, yaitu memberikan kemaslahatan masyarakat. Masyarakat yang dimaksud adalah yang menjadi konsumen bakso. Jika mereka mencampurkan zat kimia berbahaya formalin berarti mereka tidak peduli dengan kesehatan dan keselamatan konsumennya. Jadi mereka perlu memperbaiki niat dan tujuan mereka bekerja menjadi produsen bakso.

\section{Uji kandungan boraks pada bakso}

Zat kimia berbahaya lainnya yang dilarang penggunaannya pada makanan adalah boraks. Boraks menurut kamus besar bahasa Indonesia adalah bahan pembersih yang berupa hablur berwarna kuning atau serbuk berwarna cokelat. Akibat yang dapat 
ditimbulkan (Istiqomah, Sudarwanto, \& Sudarnika, 2016) antara lain anoreksia, berat badan turun, muntah, diare, ruam kulit, kebotakan (alopesia), anemia, dan konvulsi. Konsumsi terus menerus dapat mengganggu peristaltik usus, kelainan susunan saraf, depresi, dan gangguan mental. Dosis tertentu mengakibatkan degradasi mental, serta rusaknya saluran pencernaan, ginjal, hati, dan kulit karena boraks cepat diabsorpsi oleh saluran pernafasan dan pencernaan, kulit yang luka, atau membran mukosa.

Hasil penelitian menunjukan tidak ada bakso yang terindikasi boraks. Terdapat kesesuaian antara hasil kuesioner dan hasil uji laboratorium sederhana menggunakan tes kit boraks. Di desa Cibeunying boraks lebih populer digunakan pada pembuatan kupat, dengan tujuan kupat lebih kenyal dan enak. Selain sebagai pengenyal kupat, digunakan juga pada produksi kerupuk legendar supaya lebih renyah. Walaupun etika produsen makanan di desa Cibeunying masih ada yang dipertanyakan tapi secara umum untuk penggunaan boraks pada bakso tidak ditemukan.

Penggunaan bahan yang dapat mempercantik tampilan makanan, membuatnya lebih bagus hasilnya dan lebih enak rasanya, bukan berarti sehat dan aman untuk diterima oleh tubuh konsumen. Nikmat sesaat pada saat makan tetapi efek dan akibatnya dalam jangka panjang. Itu yang perlu diperhatikan oleh smua produsen makanan dan masyarakat luas sebagai konsumen. Tidak hanya produsen yang dituntut untuk cerdas dalam mengolah makanan, enak rasanya, bagus tampilannya dan aman bahan yang digunakannya. Tetapi konsumen pun dituntut untuk cerdas dalam memilih makanan mana yang bebas dari zat berbahaya. Karena setiap makanan yang terindikasi zat berbahaya memiliki ciri-ciri khusus jika diperhatikan secara mendetail.

\section{Uji kandungan babi pada bakso}

Faktor produksi terdiri atas 4 macam,(Kaaf, 2002) yaitu tenaga alam (sumber daya alam), tenaga modal, tenaga manusia, dan tenaga organisasi (manajemen). Menurut Yususf Qardhawi, empat unsur di atas memang berperan penting, namun yang paling utama dalam produksi adalah alam dan bekerja (SDA dan tenaga manusia). Sumber daya alam yang dapat dimanfaatkan oleh manusia dalam produksi diantaranya hewan, tumbuhtumbuhan, kekayaan laut, kekayaan tambang, matahari dan bulan. Bagaimana cara mengolah SDA yang telah diciptakan oleh Allah Swt.? Manusia memakmurkan bumi dengan mengelola alam berbekal ilmu dan dan akal. Selain kedua hal tersebut juga dibatasi oleh nilai dan norma. Salah satu norma yang harus dipegang adalah harus berproduksi dalam lingkaran yang halal (anjuran ini tersirat dalam QS. Al-Baqarah: 229). Disamping itu manusia juga harus memperhatikan perlindungan kekayaan alam (QS. Al-A'rof: 56, 86, 74).

Dalam surat Al-Baqarah: 173 dan AlMaidah: 3 serta beberapa hadits Nabi saw disebutkan beberapa makanan yang diharamkan dalam Islam diantaranya:

a. Bangkai

b. Darah

c. Daging babi

d. Binatang yang disembelih tidak menyebut nama Allah, yang tercekik, yang terpukul, yang jatuh, yang ditanduk, dan diterkam binatang buas kecuali yang sempat disembelih.

e. Hewan yang disembelih untuk berhala

f. Binatang bertaring dari jenis binatang buas

g. Berbagai jenis burung yang berkuku tajam

Kandungan unsur babi tidak terdeteksi dalam uji sederhana laboratorium dengan menggunakan pork detection kit. Desa Cibeunying merupakan lingkungan yang cukup agamis, ada banyak pesantren dan madrasah bediri di daerah tersebut. Dapat dikatakan hampir tidak ada masyarakatnya yang nonmuslim. Sehinga tidak heran jika tidak ditemukan adanya makanan haram tersebut. Karena tidak 
mudah mendapatkan daging babi di daerah tersebut.

Semua produsen bakso di desa Cibeunying tidak ada yang membuat bakso dari daging babi atau daging yang haram. Jangankan babi yang susah dicari di daerah tersebut, bakso udang dan dan bakso ikan saja tidak mudah ditemukan. Masih sangat jarang produsen yang membuat bakso dari selain daging sapi dan ayam. Sebagian besar produsen menggunakan daging sapi murni, ayam murni, atau campuran antara daging sapi dan ayam.

Untuk bakso ikan ada yang pernah memproduksinya, tetapi tidak banyak, dapat dikatakan dari 10 produsen hanya 1 yang pernah membuat dan menjual bakso ikan. Adapun bakso udang belum pernah ada yang membuatnya.

\section{Implementasi nilai dan moral Islam pada produsen bakso di desa Cibeunying}

Para ahli ekonomi mendefinisikan produksi sebagai "menciptakan kekayaan dengan pemanfaatan sumber alam oleh manusia"(Qaradhawi, 1997). Kahf mendefinisikan kegiatan produksi dalam perspektif Islam sebagai usaha manusia untuk memperbaiki tidak hanya kondisi fisik materialnya, tetapi juga moralitas, sebagai sarana untuk mencapai tujuan hidup sebagaimana digariskan dalam agama Islam, yaitu kebahagiaan dunia dan akhirat (Ali, 2013).

Bekerja/produksi hukumnya wajib. Allah menciptakan manusia menjadi khalifah di bumi dan memakmurkannya lewat ilmu dan amal (lihat Q.S Al-Baqarah: 30 dan Hud: 61). Bekerja/produksi memiliki norma dan nilai yang harus diperhatikan. Indikator yang menjadi tolak ukur dalam memproduksi adalah (Qaradhawi, 1997):

1. Pengolahan sumber daya alam

2. Motivasi produksi

3. Memproduksi makanan halal

4. Target swasembada individu dan masyarakat
Dari hasil pengolahan data yang diperoleh menggunakan kuesioner, penerapan nilai dan norma produksi pada indikator pertama, pengolahan sumber daya alam di desa Cibeunying mencapai 56,25\%. Sumber daya alam yang diolah dalam hal ini adalah hewan halal yang telah disembelih dengan cara yang halal. Walaupun produsen di desa Cibeunying tidak ada yang menyembelih dagingnya sendiri (mereka membeli daging di pasar), tetapi sudah dijamin kehalalannya. Jadi penerapan nilai dan norma produksi pada indikator pertama ini termasuk dalam kategori cukup baik.

Masuk dalam indikator kedua, tentang motivasi produksi. Niat dan motivasi yang mendorong mereka melakukan produksi cukup bervariasi. Ada yang bekerja karena harus menafkahi keluarga, ada yang karena senang/hobi membuatnya, ada yang memproduksi bakso karena mengetahui bakso adalah makanan yang sangat diminati oleh masyarakat Cibeunying, ada yang bekerja hanya semata-mata dalam rangka beribadah dan mencari ridha Allah, atau kombinasi dari beberapa motivasi tersebut.

Dalam hal apapun selalu harus seimbang, anatara kehidupan dunia dan akhirat, sehingga bekerja tidak hanya mencari keuntungan semata, tetapi juga mencari pahala. Sehingga dapat meningkatkan keimanan dan ketakwaan kepada Allah Sang Pencipta. Hasil pengolahan data menunjukan nilai dan moral Islam dalam motivasi produksi tergolong baik sekali, dengan angka 92,5\%.

Nilai moral yang selanjutnya adalah memproduksi makanan yang halal. Jika bahan bakunya sudah terjamin halal, bahan pelengkapnya pun harus halal. Hasil pengolahan kuesioner menunjukan $100 \%$ produsen tidak menggunakan zat kimia berbahaya ataupun menggunakan daging babi, itu berarti pencapaian yang luar biasa, penerapan etika nilai dan moral dalam tergolong terbilang baik sekali. Tetapi berbeda dengan hasil uji laboratorium sederhana menggunakan pork detectin kit. Hasil uji menunjukan bahwa terdapat bakso 
yang terindikasi formalin. Sedangkan untuk Boraks dan kandungan babi tidak terdeteksi pada sampel bakso yang telah dikumpulkan dari responden.

Produksi yang dilakukan harus memiliki target swasembada individu dan masyarakat. Bahwa membuat bakso bukan hanya mencari keuntungan semata, tetapi juga karena masyarakat banyak yang membutuhkan makanan tersebut, peduli dengan kepuasan dan kesehatan konsumennya. Pada dasarnya produsen tidak hanya memikirkan keuntungan pribadi, tetapi keuntungan yang diperoleh oleh masyarakat luas juga. Hasil penelitian di desa Cibenying penerapan nilai swasembada individu dan masyarakat menunjukan angka 88,12 \%. Secara keseluruhan, implementasi nilai dan moral Islam dalam produksi bakso di desa Cibeunying tergolong baik sekali, dengan angka $84,23 \%$.

Al-Ghazali

mengklasifikasikan

aktivitas produksi menurut kepentingan sosialnya serta menitikberatkan perlunya kerja sama dan koordinasi (Karim, 2012). Klasifikasi aktivitas produksi yang diberikan Al-Ghazali hampir mirip dengan klasifikasi yang terdapat dalam pembahasan kontemporer, (Karim, 2012) yakni:

a. Industri dasar, yakni industri-industri yang menjaga kelangsungan hidup manusia (kebutuhan primer).

b. Aktivitas penyokong (kebutuhan skunder), yakni aktivitas yang bersifat tambahan bagi indutri dasar.

c. Aktivitas komplementer (kebutuhan tersier).

Bakso bukan merupakan makanan pokok yang dapat mengancam kelangsungan hidup seseorang jika tidak memakannya. Akan tetapi makanan tersebut sudah menjadi makanan favorit yang sering dikonsumsi oleh masyarakat desa Cibeunying, sehingga jika makanan yang sering dikonsumsi mengandung bahan berbahaya akan berakibat buruk pada kesehatan konsumen. Kesehatan jasmani mempengaruhi kesehatan rohani seseorang. Karena itu membangun etika dan nilai moral Islam dalam produksi bakso menjadi sangat penting untuk diperhatikan.

\section{KESIMPULAN}

Dari hasil penelitian di atas dapat disimpulkan bahwa dari 10 bakso yang diuji ada 4 bakso yang terindikasi zat berbahaya formalin, tetapi tidak ada yang mengandung boraks dan daging babi. Selain terdapat beberapa pedagang yang menggunakan formalin (menggunakan zat berbahaya pada makanan), mereka juga telah mengatakan sesuatu yang tidak sesuai dengan sebenarnya. Mereka mengatakan tidak menggunakan formalin, tetapi pada kenyataannya ditemukan kandungan formalin pada hasil uji tes kit. Itu artinya ada beberapa pedagang yang kurang memperhatikan nilai dan moral dalam berbisnis, atau dengan kata lain tidak memperhatikan etika dalam berproduksi. Walaupn demikian, tetapi secara keseluruhan lebih banyak produsen yang masih memperhatikan etika bisnis Islam, sehingga dapat dikatakan Implementasi nilai dan moral Islam dalam memproduksi bakso yang dijual di desa Cibeunying kecamatan Majenang secara umum adalah baik.

Penerapan etika dan moral Islam dalam produksi akan membuat masyarakat tenang dan tidak khawatir ketika membeli dan memakan produksi mereka. Karena itu sangat penting untuk mengetahui seberapa jauh penerapan nilai dan moral Islam para pengusaha muslim di seluruh daerah, terutama produsen makanan, dimana sangat diperhatikan aspek kesehatan dan kesejahteraan konsumen.

\section{UCAPAN TERIMAKASIH}

Kami ucapkan terimakasih kepada DRPM KEMENRISTEKDIKTI atas dana hibah yang diberikan dalam menunjang berjalannya penelitian ini sehingga dapat terlaksana dengan lancar. Kami menyadari masih terdapat banyak kekurangan dalam penelitian ini, kritik dan saran selalu kami 
harapkan demi penelitian yang lebih baik lagi.

\section{DAFTAR PUSTAKA}

Ali, M. (2013). Prinsip dasar produksi dalam ekonomi islam. Jurnal Lisan Al Hal, 5(1), 19-34.

Amalia, F. (2013). Etika Bisnis Islam: Konsep Dan Implementasi Pada Pelaku Usaha Kecil. Al-Iqtishad: Jurnal Ilmu Ekonomi Syariah, 6(1), 116-125.

Aziz, A. (2013). Etika Bisnis Perspektif Islam: Implementasi Etika Islami untuk Dunia Usaha (Kesatu). Bandung: Alfabeta.

Bakhri, S., Leliya, \& Purnama, L. (2018). Tinjauan Etika Bisnis Islam dalam Strategi Pemasaran Home Industry Tahu Sari Rasa. Al-Mustashfa: Jurnal Penelitian Hukum Ekonomi Islam, 3(2), 285-299.

Istiqomah, S., Sudarwanto, mirnawati B., \& Sudarnika, E. (2016). Penambahan Boraks dalam Bakso dan Faktor Pendorong Penggunaannya Bagi Pedagang Bakso di Kota Bengkulu. Jurnal Sain Veteriner, (1), 1-6. https://doi.org/10.22146/jsv.22806

Kaaf, abdullah zaky al. (2002). Ekonomi dalam Perspektif Islam. bandung: pustaka setia.

Karim, adiwarman azwar. (2012). sejarah pemikiran ekonomi islam (3rd ed.). jakarta: rajagrafindo persada.

Oktriana, R. (2014). Usaha Bakso Dalam Meningkatkan Pendapatan Keluarga Menurut Perspektif Islam. Universitas Islam Negeri Sultan Sarif Kasim Riau.

Qaradhawi, Y. (1997). Norma dan Etika Ekonomi Islam. Gema Insani.

Rachmawati, Y., Rokhim, S., Munir, M., \& Agustina, E. (2018). Deteksi Kontaminan Fragmen Dna Pengkode Cyt B Babi Pada Sampel Softgellcandy Tak Berlabel Halal. Indonesia Journal of Halal, 1(1), 25. https://doi.org/10.14710/halal.v1i1.311 5

Safitri, T. (2018). Penerapan Etika Bisnis
Islam Dalam Kegiatan Produksi Kue Geti UD. Primadona Di Desa Jabalsari. IAIN Tulungagung.

Saputrayadi, A., Asmawati, A., \& Marianah, M. (2018). Analisis Kandungan Boraks dan Formalin Pada Beberapa Pedagang Bakso di Kota Mataram. IJECA (International Journal of Education and Curriculum Application), 5(2), 1. https://doi.org/10.31764/ijeca.v0i0.197 1

Suseno, D. (2019). Analisis Kualitatif dan Kuantitatif Kandungan Boraks Pada Bakso Menggunakan Kertas Turmerik, FT - IR Spektrometer dan Spektrofotometer Uv -Vis. Indonesia Journal of Halal, 2(1), 1. https://doi.org/10.14710/halal.v2i1.496 8

Wardani, R. I., Mulasari, S. A., Kesehatan, F., Universitas, M., \& Dahlan, A. (2016). Identifikasi Formalin Pada Ikan Asin Yang Dijual Di Kawasan Pantai Teluk Penyu Kabupaten Cilacap. Kes Mas: Jurnal Fakultas Kesehatan Masyarakat, 10(1), 43-48. https://doi.org/10.12928/kesmas.v10i1. 5197

Yunia, N. (2018). Implementasi Etika Bisnis Islam Dalam Menjalankan Usaha Kecil. Jurnal Aksioma Al-Musaqoh, 1(1), 30-49. 